\title{
THE BIRD IN THE CAGE: A GLIMPSE OF MY LIFE
}

\author{
TOM REGAN \\ North Carolina State University
}

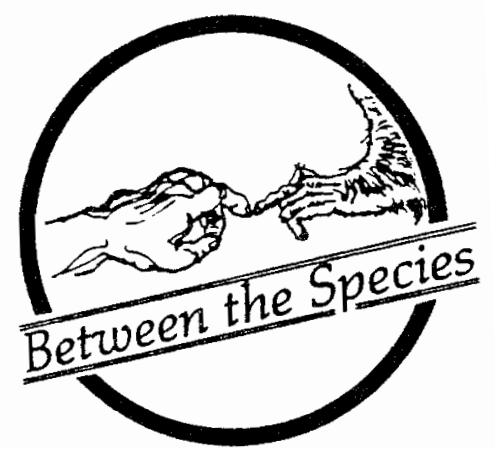

\section{BEGINNINGS: A KID OF THE STREETS}

I was born and raised in Pittsburgh, Pennsylvania--"the Burgh" as we who have lived there call it. Although I have not had a permanent residence there for more than thirty years, I still consider Pittsburgh my horne. The Burgh sets its roots deep in those who have known it. The City gets in your blood. You can't go away from home again.

The house where I spent the first fifteen years of my life fronted California Avenue, a busy thoroughfare on the city's North Side: four lanes of traffic, two trolley lines. It could get hectic. We never played ball on California Avenue. Beyond the traffic, there was a sharp drop to a leveled space some fifteen feet below the street. A dozen train tracks sliced their way westward. You could not see the trains, either from the street or from the second story windows of our house. But their relentless presence was the most dominant aspect of daily life. This was before diesel engines. Everything was stearn. That means coal-powered. The air was filled with great plumes of grayish white smoke and phosphorescent cinders that glowed in the night air. Passenger and freight trains hurried by, their whistles wailing throughout the day and all the night. Everywhere there was the crashing sound of cars being coupled and uncoupled on the Hump. Great lines of cars, hundreds at a time-freight and oil, flatbeds and cattle-were strung together by the skilled workmen. Twenty-four hours a day. seven days a week, every day of every month you heard the sound of heavy metal.

Everyone who lived along this sprawling artery that linked the coal mines of West Virginia to the steel mills of Pittsburgh belonged to the railroad. This was true even when, as in my fanily's case, no one worked for it. The soot and smoke invaded your eyes and ears, your nose and mouth, the elastic around your underwear and the clothes in your dresser. When you took a bath, a broad, dark black ring remained in the tub after you drained it, a reminder, lest one forget--how could one?-of the clanging world outside. My neighborhood was a child's paradise, a place where a kid could luxuriate in the steamy dirt of industrial, urban living.

That neighborhood is all but gone now. The house where I was raised has been demolished. In fact, the entire block of houses now is an open field, full of weeds and an occasional wildflower. Even the railroad is all but idle. Most of the houses that remain have been boarded-up, condemned as uninhabitable by the City. When I drive through the old neighborhood today, grown silent and all but deserted, I am a ghost in a ghost-town. No one from my youth remains. Viewing the fading shrouds of what was once a vibrant neighborhood, where VJ-Day and the Fourth of July were celebrated with patriotic fervor, where Jews mixed with gentiles, whites with blacks, every nationality with every other, no one would believe that there once were people here who loved these streets and narrow alley ways, the hard cement porches and creaking swings, the wooden City Steps winding to the hills above--those steps where we kids spent Friday nights fantasizing about what we would do before and after the ten cent double feature at the Brighton show on Saturday mornings. But love it I did. It always saddens me when I make my annual pil-

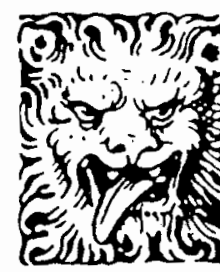


grimage and see again the stilled emptiness progress has created.

As a kid of the streets, the animals I knew were mostly the animals of the streets. Cats and dogs for the most part. But there were rats about, too--huge, menacing creatures that darted through the twisting alleys at night, their wild red eyes ablaze if caught in a beam of light. These were pitts burgh rats--creatures who could eat through a plaster wall for an evening's diversion. And there were also horses. In those days, vendors and junkmen rode four-wheeled wagons through the City, pulled by stooped shouldered nags, weary creatures who were occasionaliy aroused from their dolorous fatigue by the high pitched clang of a trolley's bell or the crack of their master's whip. The horses" droppings left more or less permanent reminders of their having passed through. I never formed a close relationship with any of these horses, nor with the cattle and pigs who bellowed and squealed through the roughsawn slats of the trucks and cattle cars en route to the slaughterhouse. Their cries fell on deaf ears in my case, blending as they did with the unbroken cacophony of urban sounds.

Tippy was another matter. One hundred percent mutt, she was an energetic black wisp of a dog with a small but clear tip of white at the very end of her tail. She was eager for affection and designed by nature to be free. Give her just the slightest crack in the gate and pow!--she was gone! like a shot, she was through the gate and around the corner. Her favorite adventure during these escapades was to roll ecstatically in the horse dung. What deep longing this primordial ritual fulfilled I do not know. But it was Nirvana for her while it lasted. I understand now that she lacked the space she needed to fill-out her nature, and I see the shadow of her stunted life in those mournful looks on so many city dogs who live in close quarters. Still, Tippy did not want for warm human companionship. My fondest memory of her is when, wonder of wonders, thirty-six inches of snow fell in Pittsburgh in a matter of a few days. That kind of development suspends all the ordinary rules of behavior. Tippy spent long hours free to wander and play, and most of this time she spent with me and the other neighborhood kids. She knew a good time when she had one. Some photographs of those days remain. It is hard to tell who is happiest--Tippy or me.

\section{EXCURSIONS: THE COUNTRY}

Not everything was urban in my youth. Along with my parents and sister, I enjoyed fishing along the upper Allegheny River and berry and nut picking in the country. We also visited friends who had farms. Sometimes, I stayed on after my parents and sister returned home--for a day, maybe a week-end, occasionally even a week. During these visits, I lived with the farm, assaulted by the pungent odor of cow dung, outsmarted by the clever laying hens who knew inexperienced hands when they felt them. (I don't think I gathered a dozen eggs, total, throughout my youthful career.) The farm I knew best was small, devoted mainly to vege-

tables and flowers. In the winter, plants were grown in a long, low-slung greenhouse. It was bewildering to enter that Iuminous space, quiet as a Church, feel the accumulated heat of the sun on a bitterly cold day and smell the sometimes dank, sometimes sweet odors of the plants. Without a doubt, these were the most mysterious, most awesome moments of my youth, occasions when my experience was so full of inchoate meanings that I could not then, and cannot now, find the words to describe it. It was, I think, more a yearning than a fact I felt.

The few animals my parents' farming friends had were members of the extended fanily. They gave, and the others took--milk and eggs. But not life. When the cow was calving, someone slept in the barn, and on very cold nights, kerosene heaters warmed the hen house. The animals had names--Bossie the cow, Bessie and Bert the chickens. Names like that. Not very imaginative, perhaps, but these names helped consolidate the bonds between the animals and their human caretakers. These farmers ate chicken--but never Bessie or Bert.

My guess is, many people of my generation had a farm like this in their childhood. Back then, families took drives in the country on Sundays; farms were places people visited in those days. And for those who lacked this opportunity, there were the stories: Henny Penny, Brer Rabbit, Black Beauty, and the breathtaking adventures of African explorers in our Weekly Reader and of Tarzan on Saturday mornings at the movies. Through these windows, we glimpsed a world apart from the piercing whistles of the steam engines in the night, heard alien sounds unlike the 
grating of huge steel wheels rolling across tracks worn sleek as silver. Urban kids of ry generation and place were bred and raised on the machine, but we took sustenance in our real and imagined commerce with the garden.

Some children understand early on what meat is. They realize that a roast or a pork chop or a chicken leg is a piece of dead animal. A corpse. I was not that precocious. Like most Americans, I grew up unmindful of the connection between the food on my plate and the death of the creature it represents. The animals I knew personally, Tippy for one, and other dogs and cats in the neighborhood, I considered my friends. Even Bossie and Bert were objects of my affection. But I lacked the imagination then to see the connection between my fondness for these animals and the silent pieces of flesh that came fron my mother's skillet or roaster. The human mind is remarkable for its ability to see the world in bits and pieces, each part disconnected from the rest like an expansive vista viewed through the narrow slits of a picket fence. It was not until much later in my life that the chronic idleness of my imagination was overwhelmed by the force of logic and the vissisitudes of experience.

\section{TRANSITION: THE BURBS}

Had my fanily remained on the North Side, it is virtually certain that I never would have gone to college. People in that neighborhood grew up to work, not to study. My parents were products of that pattern. Neither finished the ninth grade. There was work to be done, mouths to be fed. Education was a luxury. My parents were unable to pay the price.

My sister was different; she graduated from high school. But then the pattern took hold again. She went directly from the classroom to the workforce. A much better student than I was and natively much smarter, she was certain to have had a distinguished university career had she had the opportunity. Instead, she did clerical work in a nearby factory--a terrible loss I continue to lament to this day. And I? I was destined to follow my sister's lead. The duty of work called. It was not a matter of whether but where to get down to the task of making a living.

But then a momentous thing happened: we moved. To the suburbs. My parents decided that they had had it. That grime-filled heaven of my boyhood had been their hell for too long. We were getting out! No if's, and's, or but's. And I? I was fifteen, with deep roots in the friendships and places of my youth. If ever a child was resentful and full of anger, if ever hate took up lodging in a person's heart, these powerful emotions found a home in me. I was determined to be unhappy.

The world did not cooperate with my resolve. In the end, the move was not as traumatic as I was bent on making it. I made new friends and soon found myself a part of a quite different environment. Many of $m y$ friends' parents had gone to college. They had professions--in medicine, the law, education. Their taste for culture trickled down to their children and, through them, to me. I soon found myself reading and talking about Camus and Andre Gide, discussing Nietzsche and Norman Mailer, listening to Bartok and Stravinski. With my companions, I drove into and around the Burgh to watch foreign and classic films. We debated God's existence and free will into the morning hours. For the first time in my life, I began to write-horrible fiction, worse poetry. But I took the demands of the Muse seriously. And my teachers liked it. They told me I was a writer-in-the-making. They did not know the demands of the mines and the mills. Their life had found a place for the mind. And so had mine--but only an inch at a time.

Music was important. By my junior year in high school, I was making a little money playing in big dance bands and in small combos. Glenn Miller, Ted Beach, Les Elgart, Harry James, Ellington-we played all the big bands' tunes and arrangements. And as for the combos: The AJQ, the MJQ, Brubeck and Desmond, Gerry Mulligan, the early Miles Davis. We borrowed and played what we could -at small dances and parties, at wedding receptions. (Oh, the wedding receptions!) I was the lead Reed Man. I played any reed instrument in sight, but mostly clarinet and tenor sax. I doubt if I ever would have become a really good musician had I continued this career, but I did enjoy both the music and the camaraderie. In the civilian world, the closeness of rmsicians may be the nearest thing to those legendary wartime friendships formed in foxholes. 
High school, I went to college. This I did for a simple reason: it was what all my friends were doing. I then had only the faintest idea about what a college was. All I knew firsthand was that people "like me" went to one because--well, because that's what colleges were for. I was encouraged in this belief by the testimony of my teachers and other interested people. I had a good but hardly outstanding academic record in high school (top tenth of my class, as I recal1). Every Open House, all my teachers told my parents the same thing: "Tommy could do much better if only he would apply himself." "Who couldn"t?" I wondered at the time--and still do. But two people in particular--the late Reverend Iuther Fackler, who was the minister of the Lutheran Church I attended, and Ralph Pannier, who in addition to being a near neighbor also taught my sunday School class--these two men in particular. encouraged me to give college a try. Perhaps in part it is because of their mutual involvement with the Church that I have never taken the power of religion lightly--its power for the good, I mean.

Reverend Fackler had some more specific ideas in mind for me. And so did I. I thought I felt a "calling" for the ministry. But I was unsettled in my faith. Even before I went off to college, I was unable to join in the recitation of the Apostles' Creed. The words stuck in my throat. Reverend Fackler told me not to worry. God would find me--but only if I stopped trying to find Him. This seems as unsound to me now as it did then. Any god who would find me only on the condition that I was not looking for him is a god not worth finding. That much hubris any human worthy of being created by God ought to have. I wrote an essay on this issue at the time, called "The seeker," in which I affirmed this conviction. Neither perturbed nor distracted, Reverend Fackler counseled me not to worry overly much about my doubts; a true faith is measured by the depths of its temptations to deny, he said. As I was soreIy tempted in this latter regard, off I went to college, like a modern Knight Errant, to find (or, perhaps, to be found by) the Divine Mind. I chose Reverend Fackler's college-Thiel college, a small, liberal arts college affiliated with the Lutheran church, an hour and a half's drive north of Pittsburgh. I applied to no other. Ralph Pannier and his wife were most supportive. My mother and father, for a variety of reasons, were less sure, as well they should have been. I was, too. Folks from the North side could smell trouble a mile away.

\section{ON THE BANKS OF THE \\ SHENNANGO: THIEL COLLEGE}

At the beginning, college was everything my last years in high school had not been. I had a hard time making friends during my freshman year, despite playing (at' 138 pounds) halfback on the football team. To say I "played" halfback in college may be-well, actually it is an exaggeration. I dia letter in football (and in track and golf) in high school. College was a different league. I was in over my head and should have had enough sense to quit. But I didn't. It was not until my sophomore year that the Age of wisdom dawned. I never played varsity football again. But even to this day, I harbor the belief, as deep and unfalsifiable as any I have ever held, that I have good hands. You throw a ball near me and damned if I won't catch it!

Whatever Red Barber might write about my sporting life, my early academic career at Thiel was unspectacular. Mostly C's, with some $B^{\prime} S$ and $D^{\prime} s$. Something like a 2.5 averaged on a 4.0 system. Before going off to college, as I mentioned earlier, my teachers encouraged me in the belief that I might someday be a writer. I was impressionistic enough to believe them. My teachers during my first two years at Thiel seemed to be intent on demonstrating how stupid my high school teachers had been in fostering this belief in me and how duplicitous I had been in believing them. I received a more or less steady stream of $D^{\prime} s$ and $F^{\prime} s$ for my early compositions. This gave me second thoughts. Perhaps the Muse I was listening to spoke in dangling participles? Believe me, I thought long and hard about quitting more than once.

I even managed to Flunk Spanish, Elementary Spanish at that. And I received a D in English composition. I was ready to chuck it. But then--and this was perhaps the most important event in my early years as a prodigal scholar--I stopped wearing socks. I wore only tennis shoes--low cut tennis shoes. This created a persona in whose presence I was quite comfortable. I was immediately viewed as the malcontented one--different, the unfulfilled genius, the true and only real intellectual Boherian on campus. That's 
why my grades were lacklustre. I was what was then called (the wonds were almost unspeakable at the time) a Beatnik, like Allen Ginsbery, like Jack Kerouak. What a relief this sartorial gesture towards self-identity was to me! Back then, where I went to college, everyone wore socks. Only some really rare and gifted person would dare to show his bare ankles in public. I liked this cole. I began to believe in myself again. Today, given a more solid and independent selfimage, I wear my socks everywhere I go--in public, that is.

\section{TO AVOID HISTORY:}

\section{A PHILOSOPHER IS BORN}

A crisis occurred during my junior year at Thiel. I was an English major at the time and to cornplete the required course of studies I was obliged to take a full year of English history as well as a year of United states and Pennsylvania history. This was like asking me to spend two years lounging on a bed of hot coals. Whatever talents and interests I may have had, the study of history did not nourish or answer them. Fortunately for me, the forces of serendipity took charge of my life--not for the first or the last time.

Thiel was just about to introduce a new major in philosophy. I had taken a few philosophy courses by then and was pleased to discover that a subject actually existed where people discussed the questions I increasingly was inclined to ask on my own. In addition, my professors in philosophy showed an interest in me that was lacking in most of their counterparts in English. I would like to be able to say that I decided to major in philosophy because of my conmitment to pursue Truth, whatever the cost. But the really decisive factor in my decision to change was far more banal: this new major in philosophy did not require any classes in history over and above those I had already taken. That much settled, the decision was easy. I was to be Thiel college's first-ever philosophy major. It was a decision made in the stars. During my senior year, I was virtually a straight A student, barely graduating, however, because of a $D$ for the second semester of Elementary Spanish. I doubt if I could do any better today. Many are called, but few are chosen in Elementary Spanish.
By the time of my graduation from Thiel. I had abandoned any desire I may once have had to prepare myself for the ministry. I didn't know where I was headed. My summer employment as a counselor at a YMCA carm was fulfilling. Another summer's apprenticeship in a local butcher shop was not. But this was not because I found butchering ethically intolerable. I had no moral qualms whatever about preparing the ground meat, making citychicken, stocking the cold-cut section, fixing the minute steaks, or skewering the chickens'for the rotissarie. My hands went deep into the corpses of animals, but I was stone deaf to their cries. I didn't like my apprenticeship because the work was too bloody hard, not because it was too bloody. My days in the butcher's trade were numbered, but not for anything like the right reasons.

As my graduation from Thiel approached, I interviewed for a variety of jobs: selling insurance for Sears, serving as a Youth Counselor for a suburban branch of the YMCA, pursuing a career in marketing for $\mathrm{H}$. $\mathrm{J}$. Heinz. These interviews were glorious fiascos. It did not take me long to learn that I was a round peg trying to fit into square holes. And it didn't take my interviewers long to realize this, either. I knew quite well what I did not want to do. The problem was to find the round hole that answered my needs and interests. I had already postponed a vocational decision four years beyond the point of anyone else in my family, including all my relations on both sides. Not only was I the first one on either side to graduate from college, I was the first one to attend. I felt a great deal of anxiety about the need to do sonething with my life. People had been patient with me long enough. But what could a person do who had a bigger appetite for reading Kant than for selling Heinz's ketchup? That was the question whose answer eluded me.

If the idea of college was mysterious to me while I was in high school, the idea of graduate school was even more incomprehensible to me while I was in college. "What was a graduate school?" I wondered. "And what did a person do there?" I had only the faintest idea. But as my job prospects dwindled ( I was eliminated from onsideration for the YMCA job because I didn't have the "right" ideas about where blacks belonged in the particular branch where I applied; they belonged outside, I was told)--as my job prospects dwindled, I had to do something. 
And so it was that during the summer of 1960 , I applied for adnission to the Graduate School of Arts and Sciences at the University of Virginia, to continue my study of philosophy. Two weeks before the first class--at least this is my recollection--I received a letter inforning me that I had been accepted "conditionally." This meant that I was admitsted but that my status would be re-evaluated on the basis of my work during the first semester. There was, after all, enough evidence of mediocrity on my college transcript to rattle anyone's confidence. Thank heaven my major professor at Thiel was a graduate of Virginia! Had it not been for the influence and guidance of Robert S. Bryan at this time, I nay well have ended up selling collision insurance for Allstate. And this is not the least of my many debts to Bob Bryan. His influence on me is surpassed only by that of my parents. He was, and continues to be, my mentor $i r_{1}$ the deepest, truest sense.

\section{STILL UNSETTLED: \\ THE UNIVERSITY YEARS}

My graduate career at Virginia began inauspiciously enough. I was blue collar in my background. The students I met all seemed to be Blue Blood in theirs. Virginia had no female students at the time, and we Gentlemen (as we were called) wore coats and ties to class. I had one suit and two ties. I was the kid without socks who spills soup on his pants to the delight of the country club set--or so it seemed. I renember well a young man in my plato seminar, a graduate of st. John's College in Annapolis, where the education consists of reading and discussing the Great Books, many of which I had never heard of, let alone read. We were walking across the Grounds, having just passed the famous rotunda designed by Thomas Jefferson, heading toward the corner. Earlier in our seminar, we had been discussing Plato's Theatetus. I couldn't make much sense of the dialogue and was rash enough to say so. Others seemed not to find the material difficult. Stopping abruptly, my compatriot looked me squarely in the eye. Taking his pipe from his mouth (the smoking of a pipe, I discovered, was an essential mark of an educated Gentleman, one I tried to acquire, albeit unsuccessfully) and speaking with an affected British accent, he said, "Regan, you strike me as a man to whon it will not be difficult to say good-by corne the end of your first and, dare I say, your only semester."
Then he placed his pipe back in his mouth and walked away, leaving me transfixed on the spot where I stood.

I was shattered. Here I was, a kid off Pittsburgh's streets trying to make an honest go of it at Mr. Jefferson's university. And here was this $J$. Press son-of-privilege putting me in my place, telling me that I didn't belong. And who was I to deny that he was right? Didn't I think his very thoughts myself? Socially and intellectually, this was the lowest point of my life. It took me months to begin to regain any semblance of self-confidence. But in time $I$ did, and though I am not a particularly vengeful or spiteful person, I must confess that I took inore than a little pleasure when, at the end of my first senester, I was invited to continue my studies in philosophy while my sol-emn colleague from St. John's was not. I thought of it then, and I think of it now, as a stnall but real victory for the working class.

My record at Virginia was good but not great--some B's, mostly A's. I have the deepest affection for the teachers who taught me during the years I was there, and I have nothing but the most profound respect for the ideals The University embodies. I count myself very lucky, indeed, for having had the opportunity to pass through its corridors. I am the sort of person who is quietly loyal to institutions as well as to people. Though I do not belong to anything as fornal or social as a chapter of the Alumi Association, I like to think of my efforts as a teacher and philosopher as my quiet way of trying to repay The University for its patient investment in me. Doors could have been closed that were opened. I shall never forget that. To this day, one of my favorite quotes is from Jefferson; it is inscribed on the facade of the building where my seminars in philosophy were held:

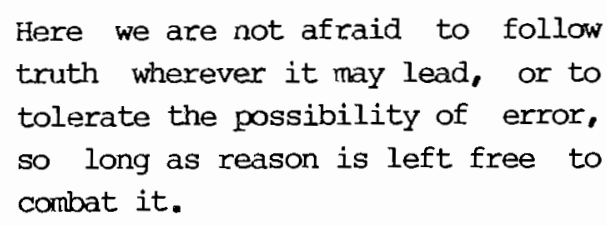

That sentiment is The University in my mind, and nothing better captures my own sense of what the spirit of rational inquiry is or should be.

But lest it seen that I slight my debts 
to Thiel, I must cite another, quite different, but no less true and important sentiment one will find inscribed on that college's sun dial. Roughly translated from the Latin, it reads:

\section{Perhaps in the future these things will appear beautiful.}

I cannot think of this observation without experiencing an involuntary shudder, as when one thinks one sees a dead friend in a crowd. The sun dial's message is right: time does soften the harsh edges of past places and events. And that is not the only truth Thiel College gave me.

\section{MORAL INNOCENCE:}

\section{ANIMALS COME AND GO}

In the spartan, no-nonsense regimen of Thiel and the more refined ambiance of Virginia, animals were all but absent. The university had some legendary dogs--lengendary largely for their proclaimed accomplishments as drinkers. Back then, students at UVA took pride in their well-deserved reputation as the biggest drinkers around. Perhaps the story is apocryphal, but one dog (Jock was his name, I think) was reputed always to have lifted his leg on the opponent's goal post at half-time during football games. And (so the story went) some two thousand people attended Jock's funeral, the dog having been killed (suitably enough, it was thought) while chasing a beer truck through the streets of Charlottesville. All this was part of the oral tradition at the university. No one I knew thought for a moment that there was anything morally dubious about getting a dog drunk or finding it really funny that old Jock would get himself killes by a truck filled with Budweiser. That I also found the story amusing at this time is symptomatic of those deeper, unarticulated beliefs I then had regarding animals, both about what they are and about how they should be treated.

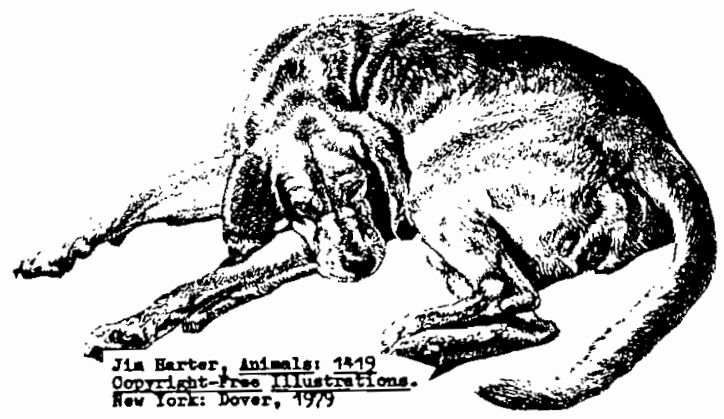

The same insensitivity I showed toward Jock's fate I exhibited in the face of a first year medical student's emotional anguish. At the beginning of my studies at Virginia, I had a room in a spotless older home only a few minutes walk from the Grounds. In the room next to mine lived the med student, a tough looking, broad-chested Polish Jew fron New Jersey, very streetwise, very determined to get ahead with his career. Even so, he did not like what he was required to do to a dog in his surgery class. He described to me how he broke the poor animal's leg and then set it, only to break and set it again. Throughout her long, painful. ordeal, the loyal animal greeted his arrival with a wag of her tail and even licked the very hands that had injured her. In the end, after he had studied one or another thing about her treatment and recovery, he was required to "euthanize" the dog. It did not sit well with him. He thought it cruel and unnecessary. He wanted to speak out, to object, but he lacked the courage. He wondered what sort of human being he was or would become. He even questioned whether he should make a career of medicine. In all this, I believe he was as sincere as anyone can be. It hurt him to hurt another, even a dog.

For my part, I was too much involved in understanding Plato's Theatetus and withstanding the insults of my peers to find time to empathize much with this medical student, let alone with the dog. I wish I could say that my ethical sensitivities regarding animals always have been highly developed. The sad truth is that they have not. The story about this dog bothered me no more and no less than the story about Jock. Animals were not on my moral map.

Among the truly major blessings in my life was my marriage to my wife Nancy on June 17. 1961. We renain indissolubly wedded, committed to our mutual growth. We are, of course, radically different people now than we were when we first met back in my sockless days at Thiel, and, perhaps, it is as much a matter of luck as it is of our love for one another that we have managed to develop in ways that have brought us closer together, rather than driving us farther apart. Sometimes, we even seem to look alike, impossible though this is--she of Lithuanian and Austrian blood, her face showing the strong beauty of her Eastern European ancestry. I of sturdy Irish stock, ruddy of complexion, 
stumped-nosed. How very fortunate we are to have settled permanently into one another.. There is so much moce one can do with one's life once the questions of a proper mate and coropanion have been answered once and for all.

Early on in our marriage, we purchased a miniature poodle. We called him "Gleco," after the name of a company we drove past every day en route to and from Charlottesville. Nancy was an instructor in special Education, teaching retarded children in the public schools. I was taking my graduate seminars. We lived in two rooms on the second floor of an older farm house about thirteen miles fron the university. The landlady was a strong-willed but friendly southern wornan who lived alone, having raised all her children after her husband, without any warning and so to everyone's surprise, committed suicide one Saturday morning-with a shotgun. She allowed her handyman to graze a few head of cattle on her pasture. Once, after a calf had been taken from his/her mother ( I did not know what had happened at the time), I approached her because of the mournful cries of the mother. All through one night and into the next day, the poor animal moaned and groaned. Surely, I told our landlady, the animal must be dying or at least be very sick. Shouldn't we do something to help her? Shouldn't we at least call the vet? Always the gentlewornan, our landlady permitted my city ignorance to pass without making much over it. Mothers worry over their children, she explained. The cow was calling out for her lost child; it was that simple. There was no need to do anything. She would forget her loss in time. As usual, this sturdy twig of a woman was right; the following day, the mother grazed contentedly. The next time I heard these same cries, I understood what they meant, only this time I thought them rather a nuisance. I remembered shouting out the window at the grieving mother, telling her to shut up. I had important work to do, and she was bothering me.

like so many newly married couples who acquire a pet, we treated Gleco as our substitute child. We took him everywhere we could, fretted over his every sign of unhappiness, felt guilt-ridden because we had to leave him alone during most days. For his part, Gleco became a loyal but in some ways an always independent companion. There was something of the cat in him, a trace of aloofness beneath the surface sheen of his

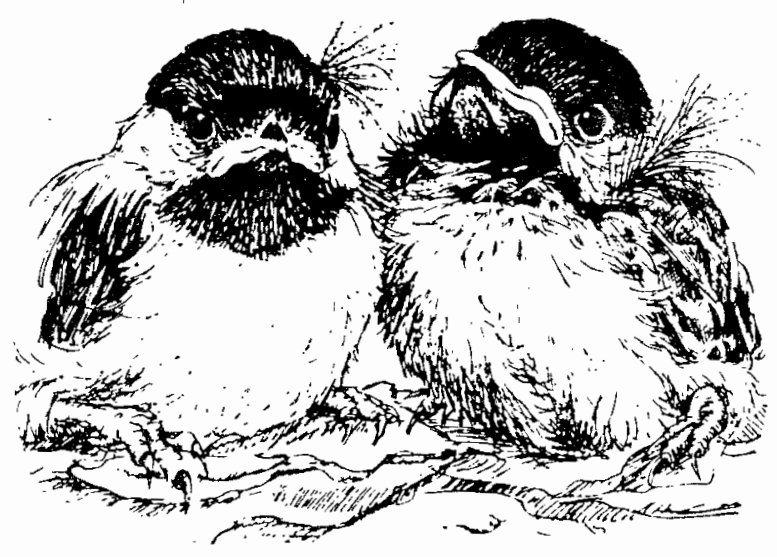

ordinary congeniality. Certainly, he refused to be taught to heel and the rest of j.t, and his frequent displays of unbridled destructiveness when we left him alone made every return home suspenseful. "What could Gleco have done today?" Nancy and I wondered as we climbed the stairs and opened the door to our rooms. What he did on some days was to rip the bed apart, devour the sofa cover, tear the bottom out of the over-stuffed arnchair, and litter the logs from the fireplace to Kingdom come. He never cared overly mich about pleasing us. But he loved us just the same, and we loved him. His subsequent death helped change my life. irreversibly.

(To be completed in the next issue)

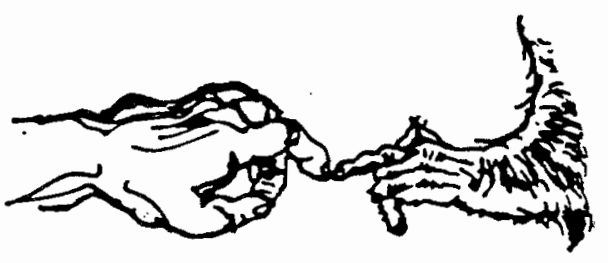

(Continued from page 18)

the fate of nonhuman animals, especially when their fate is determined by human decisions. This is the film's central message.

(For information, including information about purchasing the film in videocassette format, contact Tom Regan, President, The culture and Animals Foundation, 3590 Eden Croft Drive, Raleigh, NC 27612, or Ethel Thurston, President, The American Fund for Alternatives to Animal Research, $175 \mathrm{~W}$ 12th street, New York City, NY 10011, or Colin Smith, Executive Secretary, The International Association Against Painful Experiments on Animals, 51 Harley Street, London W1N 1DD, England.) 